НАУКОВИЙ ВІСНИК

entific messenger of $L$ wing

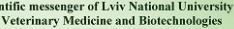

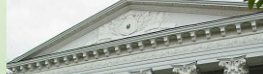

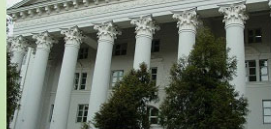

сеня "слльськогосподарсь

(2)

Науковий вісник Аьвівського національного університету ветеринарної медицини та біотехнологій імені С.3. Гжицького. Серія: Сільськогосподарські науки

Scientific Messenger of Lviv National University of Veterinary Medicine and Biotechnologies. Series: Agricultural sciences

UDC 502.1-048.34

\title{
Scientific and practical aspects of land use optimization in the agrosphere
}

\author{
S. Tsybulska, N. Hradovych, R. Paraniak \\ Stepan Gzhytskyi National University of Veterinary Medicine and Biotechnologies Lviv, Ukraine
}

\section{Article info}

Received 31.08.2020

Received in revised form 29.09 .2020

Accepted 30.09.2020

Stepan Gzhytskyi National University of Veterinary Medicine and Biotechnologies Lviv, Pekarska Str., 50, Lviv, 79010, Ukraine.

Tel.:+38-093-432-33-25

E-mail:ninagrado3@gmail.com
Tsybulska, S., Hradovych, N., \& Paraniak, R. (2020). Scientific and practical aspects of land use optimization in the agrosphere. Scientific Messenger of Lviv National University of Veterinary Medicine and Biotechnologies. Series: Agricultural sciences, 22(93), 90-96. doi: 10.32718/nvlveta9316

The article presents modern literature data on the need to improve the development of agricultural lands, taking into account the current state of agriculture. Paying attention to this issue requires special attention, as it has acquired not only theoretical but also practical significance. Intensification of negative tendencies of anthropogenic influence on edaphotope lead to a number of ecological crises of global character. We analyzed the state of land use of Lviv region and reflected the main problems of land use optimization. The dynamics of changes that took place in the structure of the land fund by types of lands is shown. An extremely important component of sustainable development of society is the quality of life provided by the continuous development of environmental innovations. The destruction of the structure of the edaphotope of the region causes the emergence and development of environmental crises and catastrophes. Preservation of high potential and quality functioning of edaphos requires changes to the constant effective maintenance of balance, which should be based on the principles of sustainable harmonious development and rationalization of land resources. In terms of regions of aridity coefficients according to research, it can be argued that natural and climatic conditions have a direct impact on the efficiency of agricultural production. Such results require a review of technologies, their modernization and the development of recommendations for their adaptation. Resource-saving land use of new territorial entities in the post-reform period includes two factors - economic and environmental. For proper organization and optimization of land holdings, it is advisable to create agro-landscapes with a clearly planned structure, which should take into account the ratio of functional-territorial orientation, economic assessment and environmental safety. This means that the main and main goal of harmonious targeted use should take into account a number of indicators of the land use system, which requires special attention to agroecosystems in the interdependent close development of environmental and economic aspects. No less important is the environmental factor of land use, as further ignoring it can create economic collapse. In this regard, the most important requirement of the time is the development, improvement and widespread implementation of resource- and energy-saving, environmentally friendly farming systems. Ecological tolerance of certain territories of land resources should be laid down in the process of designing land management developments, paying special attention to the properties of landscape ecosystems, taking into account adjacent land plots. In particular, in order to preserve the balance of agricultural landscapes, it is necessary to implement a set of preventive measures.

Key words: land use, rationalization, ecological innovations, agriculture, optimization of land structure.

\section{Науково-практичні аспекти оптимізації землекористування в агросфері}

\author{
С. Цибульська, Н. Градович, Р. Параняк
}

Львівський національний університет ветеринарної медицини та біотехнологій імені С. 3. Гжицького, м. Львів, Україна 
В статті наведено сучасні літературні дані щуодо необхідності вдосконалення розвитку земель агросфери, враховуючи сьогоденний стан сільського господарства. Звернення уваги саме на це питання потребує приділенню особливої уваги, оскільки набуло не лише теоретичного значення, а й практичного. Посилення негативних тенденцій антропогенного впливу на едафотоп призводять до ряду екологічних криз глобального характеру. Нами проаналізовано стан використання земельних ресурсів Львівської області та відображено основні проблеми оптимізачії землекористування. Показано динаміку змін, які відбулись у структурі земельного фонду за видами угідь. Надзвичайно важливою складовою сталого розвитку суспільства є якість життя, забезпечене безперервним розвитком екологічних інновацій. Руйнування структури едафотопу регіону спричиняє появу та розвиток кризисів $i$ катастроф екологічного характеру. Збереження високого потенціалу та якісного функціонування едафосу вимагає змін до постійної ефективної підтримки рівноваги, щзо повинна трунтуватися на приниипах стійкого гармонійного розвитку та раціоналізаціі ресурсів земельного фонду. В розрізі регіонів коефіцієнтів аридності згідно проведеними дослідженнями, можна стверджувати, щчо природно-кліматичні умови чинять прямий вплив на ефективність агровиробнитцва. Такі результати вимагають перегляду технологій, їх модернізації та розробку рекомендацій до їх адаптацї. Ресурсоощадне землекористування нових територіальних утворень у пореформений період включає два чинники - економічний та екологічний. Для належної постановки організації та оптимізації територій земельного фонду доцільно створювати агроландиафти з чітко спланованою структурою, де повинно враховуватись співвідношення функціонально-територіального спрямування, економічної оцінки та екологічної безпеки. Це означає, щуо головною та основною метою гармонійного иільового використання повинно враховувати низку показників системи землекористування, особливої уваги якої потребують агроекосистеми у взаємозалежному тісному розвитку аспектів екологї та економіки. Не менш важливий і екологічний чинник землекористування, оскільки подальше ігнорування його може створити крах економіки. У зв 'язку з цим найважливішою вимогою часу є розробка, вдосконалення $і$ широке впровадження ресурсо- та енергоощцадних, екологічно чистих систем землеробства. Екологічна толерантність окремих територій земельних ресурсів повинна закладатись в прочесі проектування розробок землеустрою, надаючи особливої уваги властивостям ландшафтних екосистем, враховуючи розташовані поряд земельні ділянки. Зокрема, з метою збереження рівноваги агроландщафтів необхідне впровадження комплексу превентивних заходів.

Ключові слова: землекористування, раціоналізація, екологічні інновації, сільське господарство, оптимізація структури земельних угідь.

\section{Вступ}

Сучасний стан сільського господарства свідчить про актуальність обгрунтування питань проблеми охорони і збереження навколишнього середовища в процесі розвитку агросфери. Екологічна криза зумовлюється впливом різних чинників антропогенного тиску: широке застосування у процесі аграрного виробництва різноманітних хімічних речовин, використання при виробництві продукції генетичномодифікованих організмів, порушення агротехнічних вимог обробітку тощо.

Необхідною вимогою подальшого розвитку агросфери є вдосконалення, за рахунок впровадження наукових інновацій, природоохоронної діяльності.

Особливої актуальності набуває дослідження проблем та перспектив раціонального землекористування, запровадження екологічних інновацій. Даний напрям має не лише теоретичне, але й велике практичне значення, що сприятиме прийняттю нових норм, спрямованих на екологозбалансований розвиток підприємств АПК.

Методи групування та порівняння були використані, як основні для аналізу та виокремлення проблем оптимізації землекористування на території Львівщини.

Науковцями (О. Вишневська, I. Гайдуцький, Р. Гевко, Б. Данилишин, М. Калінчик, Д. Легеза, Ю. Нестерчук, В. Печко, Н. Сіренко, О. Шебанін та ін.) представлено чисельні розробки, які розглядають проблемні аспекти екологічного характеру агроландшафтів України, а також особливості раціонального землекористування в контексті сталого розвитку. Проте недостатньо опрацьованими залишаються питання теоретико-методологічних та організаційно-прикладних засад та принципів, які додають результативності у еколого-орієнтованому спрямуванні щодо державного регулювання природоохоронної діяльності, зокрема у тому, що пов'язано із експлуатацією земельних ресуpсів (Gorbonos \& Pavlenchyk, 2005; Olijnich, 2009;
Vyshnevs'ka, 2011; Dankevych, 2013; Bobrovs'ka, 2013; Pechko, 2016).

1. Стан та динаміка використання земельних ресурсів Львівської області.

На сьогодні стан земель області характеризується посиленням процесів деградації грунтового покриву. Головною причиною, що дестабілізує екологічну ситуацію є водна ерозія, оскільки Львівщина належить до зони значної кількості опадів. Крім того, велика частина продуктивних земель перебуває під промисловими та побутовими відходами.

На рис.1. показано зміни, які відбулись у структурі земельного фонду за видами угідь у Львівській області iз 2014 р. (внутрішня частина діаграми) до 2019 p. (зовнішня частина діаграми). Як бачимо, попри деяке збільшення забудови за рахунок земель сільськогосподарського призначення, зміни у частці інших видів угідь не перевищують сотих долей відсотка.

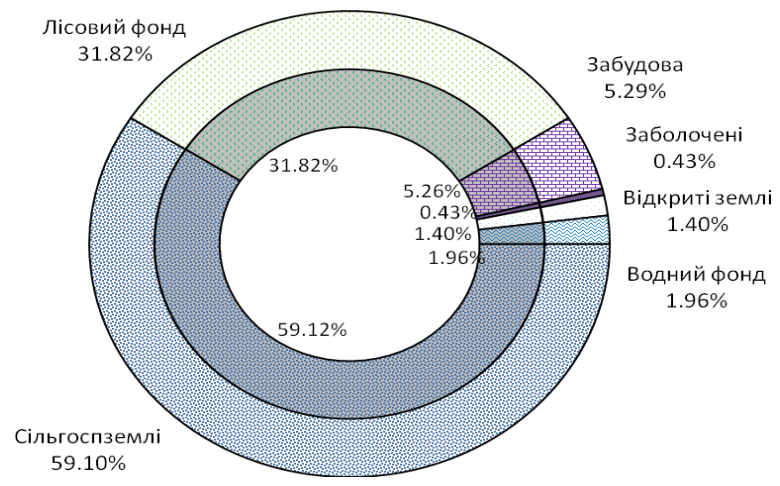

Рис. 1. Структура земельного фонду Львівської області у 2014 р.(внутрішня частина діаграми) та 2019 р. (зовнішня частина діаграми) (Oficijnyj sajt Derzhavnoi' sluzhby statystyky Ukrai'ny; Golovne upravlinnja statystyky u L'vivs'kij oblasti)

Частка забудованих земель у області $\epsilon$ порівняно невисокою, проте постійно зростаючою. Станом на 
2014 рік вона складала в середньому по області 5,3\% (найменше - у Сколівському 2,1 \%, Перемишлянському 3,0 \%, Старосамбірському $3,2 \%$ та Турківському 3,3\%; найбільше у Миколаївському 6,8 \%, Пустомитівському $6,6 \%$, Жидачівському $6,1 \%$ та Яворівському 6,0 \%). Протягом періоду 2014-2019 рр. вона зросла на $0,03 \%$ або 47065 га. Особливо суттєво спостерігалось зростання кількості категорії забудованих земель у 2017-2018 роках (рис. 2).

Забудовані землі відносять до категорії земель із несприятливим індексом екологічної стійкості. До екологічно стабільних відносять ліси, болота та землі водного фонду, до екологічно нестійких - сільгоспугіддя та райони забудови. Якщо розрахувати індекс екологічної стійкості як відношення нестабільних земель до стабільних земель, то для області у 2019 році одержимо $I=1414,3$ / 768,9 = 1,84, що є помітно більше одиниці. стабільні землі повинні становити від чверті до третини загальної площі, а отже показник екологічного ризику бажано не повинен перевищувати 2-2,5. Хоча, в цілому, по області показник нестабільності не перевищує 2, дуже ризикованими є землекористування у окремих районах, наприклад у Самбірському районі $I=5,31$, Городоцькому районі $I=4,81$, Пустомилівському районі $I=4,10$. До екологічно стабільних районів належать Сколівський із $I=0,38$ та Турківський, де $I=0,71$.

Окрім високої степені сільськогосподарського освоєння, фактором ризику є негативні процеси у грунтовому покриві, зокрема ерозії, підтоплення, забруднення земель тощо.

Описуючи фактичний стан і об'єктивні показники земельних ресурсів Львівської області варто коротко вказати на два чинники, що є важливими при дослідженні земельних ресурсів, а саме супутні природні умови та екологічний стан. Аналіз природних умов наведемо на основі загальних робіт із географії облас- ті, а стан довкілля по відношенню до земель проаналізуємо на базі екологічного паспорту Львівської обласTi.

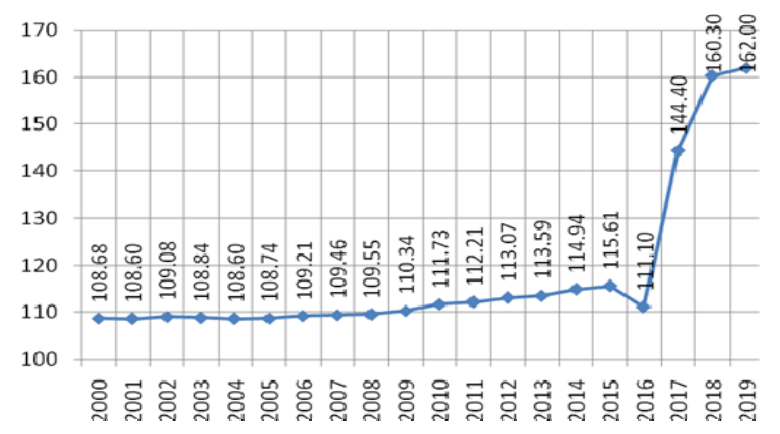

Рис. 2. Динаміка забудованих земель Львівської області у 2000-2019 pp., тис. га (Oficijnyj sajt

Derzhavnoi' sluzhby statystyky Ukrai'ny; Golovne upravlinnja statystyky u L'vivs'kij oblasti)

Важливим для збереження стану довкілля $є$ землі природно-заповідного фонду, які $є$ в особливому статусі і займають майже $7 \%$.

Критичний сучасний стан та подальший розвиток руйнівних процесів екосистем земельного фонду, що територіально належать до Львівської області, погіршує якість та властивості компонентів едафосу. Відповідно це призводить до різких змін у екосистемах агроландшафтів, породжуючи небезпеки та кризові рівні.

Фонд земельних угідь Львівщини займає 17 місце в Україні: Сільськогосподарська освоєність території - близько 60\% (59,10\% у 2015 та 57,36\% у 2019 році), лісистість (точніше землі лісового фонду, котрі можуть бути і тимчасово не вкриті лісом) - біля 32,2\% (табл. 1).

\section{Таблиця 1}

Земельний фонд Львівської області за видами угідь, тис. га (Oficijnyj sajt Derzhavnoi' sluzhby statystyky Ukrai'ny; Golovne upravlinnja statystyky u L'vivs'kij oblasti)

\begin{tabular}{lcccccc}
\cline { 2 - 6 } & $\mathbf{2 0 1 4}$ & $\mathbf{2 0 1 5}$ & $\mathbf{2 0 1 6}$ & $\mathbf{2 0 1 7}$ & $\mathbf{2 0 1 8}$ & $\mathbf{2 0 1 9}$ \\
\hline Загальна земельна площа & 2183,2 & 2183,2 & 2183,2 & 2183,2 & 2183,2 & 2183,2 \\
Сільськогосподарські землі & 1290,7 & 1290,2 & 1331,6 & 1265,8 & 1253,5 & 1252,3 \\
Землі лісового фонду & 694,7 & 694,7 & 657,8 & 657,8 & 703,3 & 703,0 \\
Забудовані землі & 114,9 & 115,6 & 111,1 & 144,4 & 160,3 & 162,0 \\
Відкриті землі заболочені & 9,4 & 9,43 & 32,5 & 32,5 & 9,4 & 9,4 \\
Відкриті землі без рослинного покриву або з & 30,6 & 30,47 & 7,4 & 39,9 & 14,3 & 14,2 \\
незначним рослинним покривом & & & & & 42,3 & 42,3 \\
Землі водного фонду & 42,8 & 42,8 & 42,8 & 42,8 & 42,4 & 42,8 \\
\hline
\end{tabular}

*сформовано автором за даними Державної служби статистики України та Львівської області

Особливості актуального стану і специфіку використання земельних ресурсів України, та Львівської області зокрема вивчали ряд науковців: Р. М. Курильців, Г. І. Бережницька, Ф. Горбонос, Н. Павленчик, М. Ступень, О. В. Шевченко, С. О. Малахова, В. П. Гордієнко, Б. І. Дяченко, Л. М. Газуда, Б. І. Пархуць, 3. Рижок, В. В. Лаврук, Н. В. Покотильська, О. С. Лаврук, I. М. Антонів, О. Б. Кузьменко та інші (Prokopenko, 2008; Andreeva \& Martynjuk, 2011; Vyshnevs'ka, 2011;
Kulynych, 2011; Savchuk \& Javors'ka, 2012; Dankevych, 2013; Rebryna, 2013; Zagvojs'ka, 2014; Berezhnyc'ka, 2019).

На сьогодні стан земель області оцінюють як такий, що поєднано з посиленням процесів деградації грунтового покриву створює загрозу екологічній та продовольчій безпеці регіону. Головною причиною, що дестабілізує екологічну ситуацію є водна ерозія, оскільки Львівщина належить до зони надлишкових 
опадів. Крім того, значна частина продуктивних земель перебуває під відходами виробництва та відвальними породами, що ще більше посилює розвиток ерозійних процесів, призводить до деградації грунтів та різкого зниження їх родючості.

За даними ГУСуЛО структура сільгоспугідь займає біля 60 \% території області (табл. 2).

\section{Таблиця 2}

Площа сільськогосподарських угідь Львівської області, га (Oficijnyj sajt Derzhavnoi' sluzhby statystyky Ukrai'ny; Golovne upravlinnja statystyky u L'vivs'kij oblasti)

\begin{tabular}{lcccccc} 
& 2014 & 2015 & 2016 & 2017 & 2018 & 2019 \\
\hline Рілля & 793810 & 794121 & 793800 & 793400 & 770900 & 772600 \\
Сіножаті & 187890 & 187640 & 187600 & 187600 & 195400 & 195200 \\
Пасовища & 256546 & 255828 & 255800 & 255700 & 250700 & 250300 \\
Багаторічні насадження & 23105 & 23242 & 23300 & 23400 & 22800 & 23200 \\
Усі с/г угіддя & 1262066 & 1261546 & 1261200 & 1260800 & 1240000 & 1241500 \\
\hline
\end{tabular}

*сформовано автором за даними Державної служби статистики України та Львівської області

Грунтовий покрив Львівщини представлений складною розмаїтою структурою, яка, відповідно, характеризується між собою різко відмінними властивостями. Це можна пояснити складними неоднорідними умовами географічного розташування території, які поділяються на округи та природносільськогосподарські райони.

Межі показників агроландшафтів дуже широкі та залежать від рівнів освоєності. Так, для прикладу, діапазон коливань може бути від 19,7 \% (гірська територія) до 46,2 \% (лісостепова зона).

Найбільша частина земель у відсотковому співвідношенні (39,6 \%) належить громадянам України, які отримали право власності чи користування.

Проте, землі агровиробничих груп та підприємств виступають основним предметом дослідження, оскільки антропогенний вплив та тиск в порівнянні $є$ значно сильніший та масштабніший. Тому варто зупинитись на ретельному вивченні та аналізі особливостей їх використання.

На жаль, земельні ресурси Львівської області за сучасними оцінками наукових досліджень є незадовільними, а в деяких випадках являються кризиснокритичними. Екологічна стійкість знижується, а екологічні руйнації грунтового покриву підсилюються.

2. Аналіз особливостей використання земельних ресурсів Львівської області у сільськогосподарських підприсмствах.

Протягом 2010-2019 рр. кількість агровиробничих груп, після зниження невпинно відновлюється. За цей же час у співвідношенні з територією України їх число значно зменшилось (10 тис. од.). Згідно принципу Гаузе виживають сильніші. У відповідності до цього можна зробити висновок, що стійкішими виявились саме ті, виробництво чи діяльність яких внесла позитивний результат матеріального характеру (рис. 3) (Berezhnyc'ka, 2019; Oficijnyj sajt Derzhavnoi' sluzhby statystyky Ukrai'ny; Golovne upravlinnja statystyky u L'vivs'kij oblasti).

Збереження високого потенціалу та якісного функціонування едафосу вимагає змін до постійної ефективної підтримки рівноваги, що повинна грунтуватися на принципах стійкого гармонійного розвитку та раціоналізації ресурсів земельного фонду. Отже, едафотоп повинен постійно досліджуватись 3 метою гармонізації соціоеколого-економічних відносин, особливо з погляду концепцій сталого розвитку.

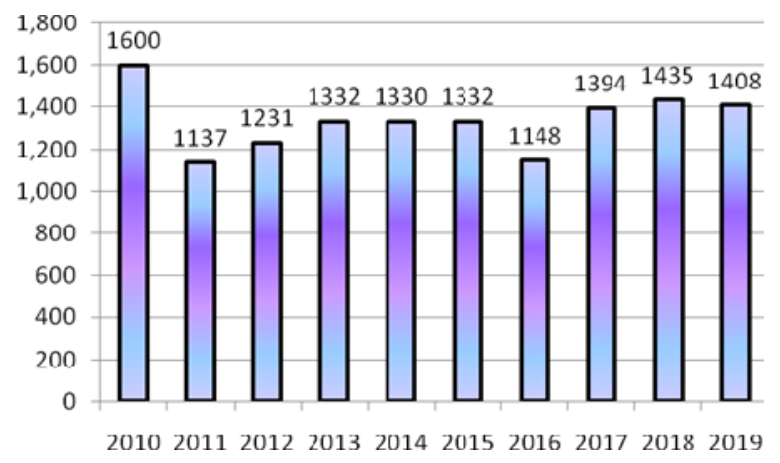

Рис. 3. Динаміка агровиробництв у розрізі 2010-2019 pp.

*сформовано автором за даними Державної служби статистики України та Львівської області

Агровиробничі групи Львівщини в більшості освоїли чорноземи. Деревисті грунти, частка яких є більшою, використовуються переважно під кормові культури. Аналізуючи структуру посіву можна зробити висновки щодо напрямку спеціалізації аграрного виробництва, а також оцінити його фактичний стан. У розрізі періоду 1994-2019 рр. бачимо, що частка кормових культур зменшилась. Останніми роками зростає попит на вирощування технічних культур. Більшу частку в структурі сільського господарства займають зернові та зернобобові культури (рис. 4).

Захоплення технічними культурами (соя, соняшник, буряк цукровий, ріпак тощо) може знижувати ефективність землеробного користування, оскільки вважається, що більшість 3 них сприяють зниженню родючості грунту. Ефективна порада превентивного характеру щодо деструкції едафотопу - компенсація виносу елементів живлення. 


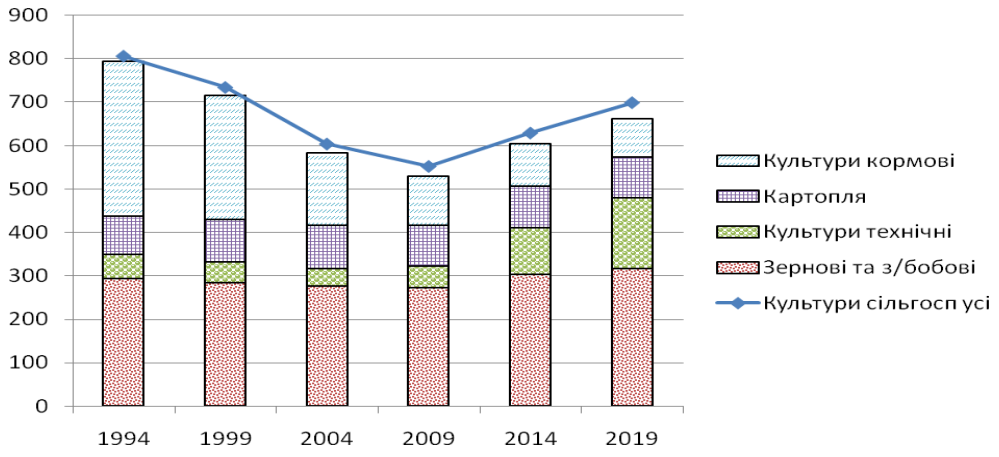

Рис. 4. Посівні площі основних сільськогосподарських культур у Львівській області у 1994-2019 рр., тис. га

(Oficijnyj sajt Derzhavnoi' sluzhby statystyky Ukrai'ny; Golovne upravlinnja statystyky u L'vivs'kij oblasti) *сформовано автором за даними Державної служби статистики України та Львівської області

Ключовими питаннями екологізації галузі сільського господарства $є$ проблеми зміни кліматичних умов та адаптації до них агровиробництва; використання земельних ресурсів й збереження грунтів; раціональне споживання та охорона водних ресурсів; розміщення відходів та забруднення атмосферного повітря; втрата біологічного розмаїття.

В розрізі регіонів коефіцієнтів аридності згідно проведеними дослідженнями, можна стверджувати, що природно-кліматичні умови чинять прямий вплив на ефективність агровиробнитцва. Такі результати вимагають перегляду технологій виробництва та розробку рекомендацій до їх адаптації.

Земельні угіддя $є$ найважливішим природним ресурсом, що відіграє ключову роль у виконанні всіх сільськогосподарських заходів, а якість грунту є основною концепцією сталого розвитку будь-якої сільськогосподарської системи.

Ресурсоощадне землекористування нових територіальних утворень у пореформений період включає два чинники - економічний та екологічний. Для належної постановки організації та оптимізації територій земельного фонду доцільно створювати агроландшафти 3 чітко спланованою структурою, де повинно враховуватись співвідношення функціональнотериторіального спрямування, економічної оцінки та екологічної безпеки. Це означає, що головною та основною метою гармонійного цільового використання необхідно враховувати низку показників системи землекористування, особливої уваги якої потребують агроекосистеми у взаємозалежному тісному розвитку аспектів екології та економіки. Не менш важливий і екологічний чинник землекористування, оскільки подальше ігнорування його може створити крах економіки.

Оптимізація системи землекористування повинна базуватись на показниках продуктивності агровиробничих груп грунтів. Для побудови і належного гармонійного функціонування обов'язковим $є$ врахування економічної оцінки структури сільського господарства (Prokopenko, 2008; Rebryna, 2013). Не менш важливий і екологічний чинник землекористування, оскільки подальше ігнорування його може призвести до краху економіки. У зв'язку з цим найважливішою вимогою часу $є$ розробка, вдосконалення і широке впровадження ресурсо- та енергоощадних, екологічно чистих систем землеробства.

Екологічна толерантність окремої земельної ділянки як складової ландшафту потрібно закладати в процесі розробки землевпорядного проекту, враховуючи ландшафтні властивості поряд розташованих ділянок і запобігаючи рівноваги ландшафтного комплексу перед тим, як ділянка буде передана власність чи користування суб'єктів господарювання.

На жаль, згідно оцінок експертів, досягнуто критичного рівня щодо загального стану земельного фонду в Україні. Щорічне зниження важливих цінних показників грунту призводить не тільки до економічних збитків, а й веде до появи зростаючої тенденції порушених земель. Екологічні руйнівні впливи діяльності агросфери, зумовлені повільними темпами розвитку охорони земель та їх раціонального користування. Конкретні оцінки ж по Львівській області дещо різняться. Консенсус існує щодо загальної кількості порушених земель (Prokopenko, 2008; Savchuk \& Javors'ka, 2012; Rebryna, 2013; Pechko, 2016; Cherechon, 2017).

Чимала частка земель Львівщини може бути віднесена до земель із середнім та низьким рівнем продуктивності, оскільки характеризуються низькою еколого-економічною ефективністю. Цілеспрямовані і багаторічні роботи із поліпшення стану земель ведуться вкрай епізодично й фрагментарно. Енергетична продуктивність грунту обов'язково повинна враховуватись при впровадженні еколого-економічних механізмів 3 охорони та відтворення агроландшафтів.

Ресурсоощадна діяльність агросфери повинна комплексно охоплювати територіальні умови агроекосистем і природоохоронні заходи. Чимало науковців вважають, що в нашій країні можна сміло виокремити групу людей (до 5 \%), які віддають перевагу споживанню продукції органічного спрямування. Цей вияв сприятиме подальшому розвитку високої якості харчування, а також зумовить підвищення родючості грунту та природоохоронної системи загалом. Проте у більшості випадків така частка співвідношення $\epsilon$ недостатньою для широкого впровадження органічних методів землеробства. В умовах ринкових відносин світового масштабу можна зробити висновки, що стимулювання підвищеного прояву інтересу людей до споживання органічної продукції пояснюється гаран- 
тійними сподіваннями на якісне та безпечне харчування (без використання ГМО), при цьому головною ідеологією виступає збереження довкілля.

Досліджено, що в Україні спостерігається ситуація систематичного недофінансування сфери охорони навколишнього природного середовища. Аналіз структури витрат на охорону навколишнього природного середовища в розрізі джерел фінансування в 2017 році показує, що основним джерелом фінансування були власні кошти підприємств та організацій, на долю яких припадало 77 \% загального обсягу витрат на природоохоронні заходи.

Доведено необхідність фінансового забезпечення екологізації аграрної сфери економіки на всіх рівнях локальному, регіональному та державному. Фінансування природоохоронних заходів носить поточний, а не стратегічний характер (Olijnich, 2009; Kulynych, 2011; Illjashenko, 2012).

3. Перспективи й напрями раціоналізації землекористування.

Досвід країн СС свідчить про активізацію запровадження еко-інновацій, які грунтуються на фінансуванні заходів з технологічного переозброєння галузі у напряму отримання екологічних вигід від практичного використання (Berezhnyc'ka, 2019). Запровадження екологічних принципів додадуть результативності у еколого-орієнтованому спрямуванні щодо державного регулювання природоохоронної діяльності, зокрема у тому, що пов'язано із експлуатацією земельних ресурсів.

У сучасних умовах господарювання земельні ресурси є основою виробничо-господарської діяльності сільськогосподарських підприємств. Їх ефективне використання має грунтуватись на інтенсивних методах ведення господарювання.

Оптимізація структури землекористування включає такі заходи, як консервування еродованих земель, залуження та заліснення ріллі, консолідація тощо.

Значна площа порушень зумовлює необхідність проведення масштабних науково-обгрунтованих фітомеліоративних і рекультиваційних заходів, що передбачає необхідність розробки технологічних класифікацій порушених екосистем (Kulynych, 2011; Savchuk \& Javors'ka, 2012).

Оптимізацію земель Львівської області необхідно реалізовувати за основними напрямками, що включали б: збільшення площі еколого-стабілізуючих угідь; вдосконалення плану розвитку системи чергування сільськогосподарських культур; консервацію та рекультивацію еродованих територій.

Останнім часом все частіше використовують термін ревіталізація, зокрема і щодо поліпшення стану та продуктивності порушених земель, подальших перспектив їх використання.

Основними принципами ревіталізації техногенно порушених земель $є$ :

1. Відновлений ландшафт має бути кращим за icторичний;

2. Наукове прогнозування поведінки нерівноважних систем;

3. Порівняння витрат з можливими збитками;

4. Опора на процеси природного самовідновлення;
5. Постійний моніторинг і коректування проектів;

6. Розмежування компенсаційних витрат і інвестицій;

7. Гарантійне фінансування.

При розв'язанні проблем, викликаних надмірним використанням земельних ресурсів необхідним $є$ :

$\checkmark \quad$ глибокий аналіз процесів екодеструктивного впливу та постійний моніторинг за цими змінами у масштабному співвідношенні;

$\checkmark \quad$ впровадження заходів ревіталізації земель для ліквідації негативних наслідків впливу діяльності даних підприємств;

$\checkmark$ удосконалення системи моніторингу деградації земельних ресурсів, а також ведення моніторингу їх розвитку зі збільшенням пунктів спостережень.

Сьогодні при веденні землеробства біологізація технологій є чи не єдиним заходом, який може стримати подальше зниження родючості грунтів, стабілізувати виробничі системи, знизити залежність від технологічних факторів i таким чином підвищити конкурентоспроможність сільськогосподарського органічного виробництва зерна на внутрішньому та зовнішньому ринках продовольства.

Агротехнології та сівозміни дають змогу розробляти технологію вирощування сільськогосподарських культур з урахуванням їх взаємного впливу, а також після дії кожного заходу, що застосовується під найближчі попередники (Gorbonos \& Pavlenchyk, 2005; Illjashenko, 2012; Dankevych, 2013; Zagvojs'ka, 2014). Ось чому зростання культури землеробства може бути забезпечене лише в разі дотримання науковообгрунтованих сівозмін, які відповідають конкретним природнокліматичним умовам і спеціалізації сільськогосподарського виробництва.

Подальший розвиток постіндустріальних технологій потребує використання системних підходів та інформаційної бази для вибору раціональних біологізованих сівозмін відповідно до умов конкретного сільськогосподарського підприємства.

Збільшення частки органічного землеробства можна вважати одним із елементів реалізації екологоорієнтованого підходу до використання земельних ресурсів Львівської області (Olijnich, 2009; Illjashenko, 2012).

Формування основ зрівноваженого розвитку аграрного сектора повинно грунтуватися на екологоорієнтованому підході, а регіональна економічна політика повинна надавати переваги окремим галузям, видам діяльності, формам господарювання за достатності фінансування (Bobrovs'ka, 2013). Залежно від рівнів управління у розвитку повинні встановлюються не тільки на державному рівні управління, а і на локальному, у тому числі через активізацію інвестиційних потоків у вирішення екологічних завдань. Для формування основ зрівноваженого розвитку необхідним $\epsilon$ забезпечення розвитку альтернативної енергетики, розвиток органічного землеробства.

\section{Висновки}

Підсумовуючи наведені вище результати наукових досліджень останніх років та порівнюючи статистичні 
дані у розрізі певного часового періоду, варто зазначити, що, в цілому, агроландшафти Львівщини характеризуються низьким рівнем екологічної стійкості.

Для локалізації негативної дії деградаційних процесів, які проявляються на територіі досліджуваного регіону, необхідно втілювати у життя систему природоохоронних заходів як важливу складову оптимізаціі сільськогосподарського землекористування. Львівщина потребує збільшення площі екологостабілізуючих угідь для подальшої оптимізації, а також упровадженні гідротехнічних споруд для зниження частки руйнівних факторів. Подальше впровадження екологічних інновацій забезпечить економічний розвиток і захист довкілля.

Отже, проведений аналіз та запропоновані рекомендації можуть стати ефективним інструментом розвитку традиційних знань землекористування в нашій країні.

\section{References}

Andreeva, N. N., \& Martynjuk, E. N. (2011). Jekologicheskie innovacii i investicii: sushhnost', sistemologija, specifika vzaimodejstvija i upravlenija. Visnyk Khmelnytskoho nacionalnogo universytetu, 2(2), 205-209 (in Ukrainian).

Berezhnyc'ka, G. I. (2019). Specyfika gospodars'kogo vykorystannja zemel'nyh resursiv sil's'kogospodars'kyh pidpryjemstv L'vivs'koi' oblasti. Social'no-ekonomichni problemy suchasnogo periodu Ukrai'ny, 2, 54-59. URL: http://nbuv.gov.ua/UJRN/sepspu_2019_2_12 (in Ukrainian).

Bobrovs'ka, N. V. (2013). Ekologo-orijentovanyj pidhid u rozvytku agrarnogo sektora. Visnyk Sums'kogo nacional'nogo agrarnogo universytetu. Serija: Ekonomika i menedzhment, 4, 175-178 (in Ukrainian).

Cherechon, O. (2017). Osnovni zahody optymizacii' struktury zemlekorystuvannja. Visnyk L'vivs'kogo nacional'nogo agrarnogo universytetu. Serija: Ekonomika APK, 24(2), 79-83. URL: http://nbuv.gov.ua/UJRN/Vlnau_econ_2017_24\%282 $\% 2918$ (in Ukrainian).

Dankevych, V. Je. (2013). Osoblyvosti vykorystannja svitovyh zemel'nyh resursiv. Ekonomichnyj prostir, 74, 15-23 (in Ukrainian).

Golovne upravlinnja statystyky u L'vivs'kij oblasti. Baza danyh [Elektronnyj resurs]. URL: http://www.lv.ukrstat.gov.ua (in Ukrainian).
Gorbonos, F., \& Pavlenchyk, N. (2005). Do pytannja racional'nogo vykorystannja zemel'nyh resursiv. Visnyk L'viv. derzh. agrar. un-tu: Zemlevporjadkuvannja i zemel'nyj kadastr. L'viv, 8, 10-15 (in Ukrainian).

Illjashenko, S. M. (2012). Analiz rynkovyh mozhlyvostej i potencialu innovacijnogo rozvytku organizacii' na bazi ekologichnyh innovacij. Marketyng i menedzhment innovacij, 3, 229-241 (in Ukrainian).

Kulynych, P. F. (2011). Pravovi problemy ohorony i vykorystannja zemel' sil's'kogospodars'kogo pryznachennja v Ukrai'ni: monografija. K.: Logos (in Ukrainian).

Oficijnyj sajt Derzhavnoi' sluzhby statystyky Ukrai'ny [Elektronnyj resurs]. URL: www.ukrstat.gov.ua (in Ukrainian).

Olijnich, E. I. (2009). Razvitie jekologicheskih innovacij v uslovijah tehnoglobalizma. Nierovnosci spoleczne a wzrost gospodarczy. Rzeszow, Poland, 14, 312-320. URL: http://www.ur.edu.pl/pliki/Zeszyt14/25.pdf.

Pechko, V. S. (2016). Pidvyshhennja efektyvnosti vykorystannja zemel' sil's'kogospodars'kyh pidpryjemstv $\mathrm{v}$ umovah stalogo rozvytku [Tekst] : avtoref. dys. ... kand. ekon. nauk: 08.00.04. Harkiv. nac. agrar. un-t im. V. V. Dokuchajeva. Harkiv, 20 (in Ukrainian).

Prokopenko, O. V. (2008). Ekologizacija innovacijnoi' dijal'nosti: motyvacijnyj pidhid: monografija. Sumy: VTD “Universytets'ka knyga” (in Ukrainian).

Rebryna, N. (2013). Ekologichni innovacii' jak instrument dosjagnennja ekologichnoi' bezpeky transkordonnogo regionu. Naukovyj visnyk Shidnojevropejs'kogo nacional'nogo universytetu imeni Lesi Ukrai'nky, 9, 2629. URL: https://scholar.google.com/scholar?cluster= $6181959981772779938 \& \mathrm{hl}=\mathrm{uk} \&$ as $\mathrm{sdt}=0,5 \&$ sciodt $=0$, 5 (in Ukrainian).

Savchuk, O. Ja., \& Javors'ka, N. P. (2012). Konceptual'ni pidhody do utochnennja ponjattja "ekoinnovacii". Naukovyj visnyk NLTU Ukrai'ny, 22(4), 106-113. URL: https:/cyberleninka.ru/article/n/kontseptualni-pidhodido-utochnennya-ponyattya-eko-innovatsiyi/viewer (in Ukrainian).

Vyshnevs'ka, O. M. (2011). Resursnyj potencial agrarnogo sektora ekonomiky Ukrai'ny: social'noekonomichni ta ekologichni aspekty: monografija. Mykolai'v (in Ukrainian).

Zagvojs'ka, L. D. (2014). Konceptualizacija ekoinnovacij u konteksti suchasnogo ekologo-ekonomichnogo dyskursu. Visnyk ONU imeni I. I. Mechnykova, 19(2/5), 17-20 (in Ukrainian). 